\title{
Особливості бактеріальної контамінації перитонеуму та кишки при різних стадіях гострої злукової тонкокишкової непрохідності та її корекції
}

\author{
Мета роботи: з’ясувати особливості бактеріальної контамінації перитонеуму та кишки при різних стадіях гострої злукової \\ тонкокишкової непрохідності та її корекції. \\ Матеріали і методи. Обстежено та прооперовано 152 хворі на гостру злукову тонкокишкову непрохідність. 3 них 58 (38,2 \%) \\ пацієнтів були в стадії компенсації та 94 (61,8 \%) пацієнтів - у стадії декомпенсації. 3 метою вивчення рівня бактеріальної \\ транслокації виконували бакпосів виділень із дренажів та назогастроінтестинального (НГI) зонда в динаміці лікування у \\ післяопераційному періоді. \\ Результати досліджень та їх обговорення. У роботі вивчено кількісний і якісний склад мікрофлори тонкої кишки та \\ перитонеального ексудату під впливом комплексного лікування із застосуванням лаважу кишечника 0,9 \% розчином натрію \\ хлориду в поєднанні з оксигенотерапією та ентеральним харчуванням розчином “Пептамен” у хворих на гостру злукову \\ тонкокишкову непрохідність у стадії компенсації та декомпенсації. Виявлено меншу колонізацію кишечника та контамінацію \\ черевної порожнини кишковою паличкою, умовно-патогенними мікроорганізмами, та більш швидке відновлення біоценозу тонкої \\ кишки при застосуванні розробленого комплексу заходів дозволило знизити рівень післяопераційних ускладнень та летальності.
}

Ключові слова: гостра злукова кишкова непрохідність; бактеріальна транслокація; назогастроінтестинальний зонд.

Постановка проблеми і аналіз останніх досліджень та публікацій. Серед причин механічної кишкової непрохідності на першому місці знаходиться гостра злукова кишкова непрохідність (ГЗКН), частота якої становив 60 \%, що зумовлено щорічним зростанням кількості пацієнтів, оперованих на органах черевної порожнини $[1,2]$. Високий рівень летальності при цьому захворюванні зумовлений розвитком ендотоксикозу та поліорганної недостатності [3].

Патогенез порушень при ГКН передусім пов’язаний з порушенням бар'єрної функції кишкової стінки та розвитком синдрому кишкової недостатності $[4,5]$. Розвиток кишкової непрохідності супроводжується транслокацією бактерій, які колонізують просвіт кишечника, порушенням їх співвідношення на користь умовно-патогенних бактерій. Характер бактеріальної транслокації (БТ) визначається станом слизової оболонки кишечника, імунної системи та складом колонізуючої мікрофлори [3, 6]. Надмірна колонізація тонкого кишечника здійснюється за рахунок обсіменіння різноманітними бактеріальними популяціями з дистальних відділів кишечника. Кишковий стаз і парез призводить до швидкого збільшення концентрації внутрішньокишкової мікрофлори та резорбції токсинів, особливо в тонкому кишечнику [7].

Дослідження мікробіоценозу кишечника та ексудату черевної порожнини у хворих з гострою кишковою непрохідністю є вкрай важливим для оцінки стану хворого та прогнозу перебігу післяопераційного періоду.

Мета роботи: з'ясувати особливості бактеріальної контамінації перитонеуму та кишки при різних стадіях гострої злукової тонкокишкової непрохідності та ії̈ корекції.

Матеріали і методи. В основу нашого дослідження покладено аналіз клінічного обстеження та хірургічного лікування 152 хворих на гостру злукову тонкокишкову непрохідність. 3 них 58 (38,2 \%) пацієнтів були в стадії компенсації та 94 (61,8 \%) пацієнти - в стадії декомпенсації.

Обстежувані хворі були розподілені на 3 основні групи (№ 1, № 2, № 3). В основну групу № 1 (n=58) ввійшли пацієнти в стадії компенсації, яким було виконано роз'єднання злук та дренування черевної порожнини. В основну групу № 2 $(\mathrm{n}=49)$ ввійшли пацієнти в стадії декомпенсації, яким після ліквідації причини кишкової непрохідності інтраопераційно виконували назогастроінтестинальну інтубацію (НГІІ). Пацієнтам цієї групи в післяопераційному періоді інкубаційний (НГІ) зонд використовували лише для декомпресії та пасивного відтоку кишкового вмісту. Основну групу № 3 (n=45) склали пацієнти в стадії декомпенсації, яким після ліквідації причини кишкової непрохідності інтраопераційно виконували НГІІ. Пацієнтам цієї групи в післяопераційному періоді НГІ зонд використовували для проведення лава- 
жу, оксигенотерапії (Патент України на корисну модель № 81097) та ентерального харчування. Лаваж кишечника проводили 0,9 \% розчином $\mathrm{NaCl}$, ентеральне харчування розпочинали з появою перистальтики (2-3 доба післяопераційного періоду) за допомогою розчину “Пептамен”.

3 метою вивчення рівня бактеріальної транслокації виконували бакпосів виділень із дренажів та НГІ зонда в динаміці лікування через 1, 3 та 5 діб післяопераційного періоду. Мікробіологічні дослідження здійснювали загальноприйнятими методами [8].

Отримані цифрові дані обробляли статистично. Вірогідність відмінностей між дослідними і контрольною групами оцінювали з використанням програми STATISTICA (“StatSoft, Inc.”, США) на основі непараметричного критерію Манна-Уітні.

Результати досліджень та їх обговорення. При аналізі мікробіологічних досліджень встановлено, що па першу добу після операції кількість умовно-патогенних ентеробактерій (E. coli, Proteus vulgaris, Klebsiella spp., Enterobacter cloaceae) у виділеннях із дренажів у першій групі хворих складала $(4,57 \pm 0,14) \mathrm{KУO/г,} \mathrm{дещо} \mathrm{вищим} \mathrm{цей} \mathrm{показ-}$ ник був в третій групі хворих - $(5,33 \pm 0,12) \mathrm{KУO} / \Gamma$ та найвищим - в другій групі $(6,09 \pm 0,15) \mathrm{KУO} / \Gamma$ (табл. 1). Оскільки в першій групі хворих НГІ зонд не використовували, оцінку бактеріального пейзажу виділень із зонда проводили в другій та третій групі хворих. Так, кількість облігатних анаеробних мікроорганізмів (Bifidumbaccilus, Lactobaccilus) та кількість E. coli в досліджуваних групах була майже на одному рівні станом на першу добу після операції $(4,00 \pm 0,14)$ і $(3,80 \pm 0,14)$ КУО/Г - облігатні анаеробні мікроорганізми, $(7,12 \pm 0,21)$ і $(7,10 \pm 0,14) \mathrm{KУO} / г$ - Е. coli відповідно (табл. 1). Ці показники значно відрізнялись від норми $((7,6 \pm 0,20) \mathrm{KУO/Г} \mathrm{-} \mathrm{нормальний} \mathrm{рівень} \mathrm{бі-}$ фідум- та лактобактерій, $(1,50 \pm 0,10)$ КУО/г - нормальний рівень E. coli в тонкому кишечнику), що може свідчити про глибокий дисбіоз тонкого кишечника, спричинений даною патологією.

На третю добу після операції у виділеннях із дренажів спостерігали зниження рівня умовнопатогенних ентеробактерій в 1,5 раза порівняно 3 першим післяопераційним днем у першій групі хворих $((3,13 \pm 0,23)$ і $(4,57 \pm 0,14)$ КУО/г відповідно) (табл. 1, 2).

У другій та третій групі хворих зниження обсіменіння внутрішньочеревного ексудату на третю добу виявилось незначним і становило $(4,94 \pm 0,18)$ КУО/г та $(4,00 \pm 0,18)$ КУО/г відповідно (табл. 2). При посівах вмісту із НГІ зонда на третій день після операції спостерігали зниження більш ніж на 25 \% кількості облігатних анаеробних мікроорганізмів $((2,73 \pm 0,13) \mathrm{KУO/г)} \mathrm{у} \mathrm{другій} \mathrm{групі} \mathrm{хворих}$ на противагу кількісного рівня E. coli, який був в межах $(6,82 \pm 0,17)$ КУО/г. Ці дані можуть свідчити про посилення дисбіотичних змін в тонкому кишечнику хворих другої групи.

Кількісний склад облігатних анаеробних мікроорганізмів, виділених із зонда хворих другої групи, не зазнав суттєвих змін на третю добу після операції і незначно зріс порівняно з першим днем після операції та становив $(4,13 \pm 0,14) \mathrm{KУО/г.} \mathrm{Про-}$ те кількісний склад E. coli, виділеної із зонда хворих третьої групи, знизився майже на $20 \%$ і становив $(5,80 \pm 0,14) \mathrm{KУО/Г,} \mathrm{що} \mathrm{свідчить} \mathrm{про} \mathrm{позитивну}$ динаміку відновлення мікробіоценозу тонкого кишечника хворих третьої групи (табл. 2).

На п’яту добу після операції спостерігали значне зниження бактеріального обсіменіння виділень із черевної порожнини в першій групі хворих у стадії компенсації та в третій у стадії декомпенсації, яким у післяопераційному періоді проводили комплекс лікувальних заходів за запропонованим способом. У другій групі хворих, пролікованих за традиційними методиками, на п'яту післяопераційну добу кількість умовно-патогенних ентеробактерій знизилась незначно порівняно $з$ третьою добою $((4,33 \pm 0,12) \mathrm{i}$ $(4,94 \pm 0,18) \mathrm{KУO/г} \mathrm{відповідно)} \mathrm{(табл.} \mathrm{3).}$

Таблиця 1. Показники бактеріального спектра виділень із назогастроінтестинального зонда та випоту перитонеального ексудату із дренажів в оперованих хворих при різних стадіях гострої злукової тонкокишкової непрохідності на першу добу післяопераційного періоду (M $\pm \mathrm{m})$, Ig KУO/г

\begin{tabular}{|c|c|c|c|}
\hline \multirow[b]{2}{*}{ Групи хворих } & \multicolumn{2}{|c|}{ Бактеріальний пейзаж виділень із зонда } & Бактеріальний пейзаж виділень із дренажів \\
\hline & $\begin{array}{l}\text { кількісний склад облігатних } \\
\text { анаеробних мікроорганізмів }\end{array}$ & $\begin{array}{l}\text { кількісний } \\
\text { склад E. coli }\end{array}$ & $\begin{array}{c}\text { кількісний склад умовно-патогенних } \\
\text { ентеробактерій }\end{array}$ \\
\hline Основна $1(n=58)$ & $*$ & $*$ & $0,91 \pm 0,11$ \\
\hline Основна $2(n=49)$ & $5,47 \pm 0,18$ & $5,82 \pm 0,13$ & $4,33 \pm 0,12$ \\
\hline Основна 3 (n=45) & $6,09 \pm 0,15$ & $2,63 \pm 0,12$ & $0,67 \pm 0,12$ \\
\hline
\end{tabular}

Примітка. *- НГІ зонд відсутній. 
Таблиця 2. Показники бактеріального спектра виділень із назогастроінтестинального зонда та випоту перитонеального ексудату із дренажів в оперованих хворих при різних стадіях гострої злукової тонкокишкової непрохідності на третю добу післяопераційного періоду (M \pm m), Ig KУO/г

\begin{tabular}{||c|c|c|c||}
\hline \multirow{2}{*}{ Групи хворих } & \multicolumn{2}{|c|}{ Бактеріальний пейзаж виділень із зонда } & Бактеріальний пейзаж виділень із дренажів \\
\cline { 1 - 4 } & $\begin{array}{c}\text { кількісний склад облігатних } \\
\text { анаеробних мікроорганізмів }\end{array}$ & $\begin{array}{c}\text { кількісний } \\
\text { склад Е. coli }\end{array}$ & $\begin{array}{c}\text { кількісний склад умовно-патогенних } \\
\text { ентеробактерій }\end{array}$ \\
\hline Основна 1 $(\mathrm{n}=58)$ & $*$ & $*$ & $4,57 \pm 0,14$ \\
\hline Основна 2 $(\mathrm{n}=49)$ & $4,00 \pm 0,14$ & $7,12 \pm 0,21$ & $6,09 \pm 0,15$ \\
\hline Основна 3 $(\mathrm{n}=45)$ & $3,80 \pm 0,14$ & $7,10 \pm 0,14$ & $5,33 \pm 0,12$ \\
\hline \hline
\end{tabular}

Примітка. *- зонд відсутній.

Таблиця 3. Показники бактеріального спектра виділень із назогастроінтестинального зонда та випоту перитонеального ексудату із дренажів в оперованих хворих при різних стадіях гострої злукової тонкокишкової непрохідності на п'яту добу післяопераційного періоду (M $\pm \mathrm{m})$, lg KУO/г

\begin{tabular}{||c|c|c|c||}
\hline \multirow{2}{*}{ Групи хворих } & \multicolumn{2}{|c|}{ Бактеріальний пейзаж виділень із зонда } & Бактеріальний пейзаж виділень із дренажів \\
\cline { 1 - 4 } & $\begin{array}{c}\text { кількісний склад облігатних } \\
\text { анаеробних мікроорганізмів }\end{array}$ & $\begin{array}{c}\text { кількісний } \\
\text { склад Е. coli }\end{array}$ & $\begin{array}{c}\text { кількісний склад умовно-патогенних } \\
\text { ентеробактерій }\end{array}$ \\
\hline Основна 1 $(\mathrm{n}=58)$ & $*$ & $*$ & $3,13 \pm 0,23$ \\
\hline Основна 2 $(\mathrm{n}=49)$ & $2,73 \pm 0,13$ & $6,82 \pm 0,17$ & $4,94 \pm 0,18$ \\
\hline Основна 3 $(\mathrm{n}=45)$ & $4,13 \pm 0,14$ & $5,80 \pm 0,14$ & $4,00 \pm 0,18$ \\
\hline
\end{tabular}

Примітка. *- зонд відсутній.

Кількість облігатних анаеробних мікроорганізмів у просвіті тонкого кишечника на п’яту добу післяопераційного періоду зросла як в другій, так і в третій групі хворих, що свідчить про позитивну динаміку відновлення облігатної мікрофлори тонкого кишечника (табл. 3). Проте кількісний рівень кишкової палички в виділеннях з НГІ зонда у другій групі хворих перевищував вдвічі $((5,82 \pm 0,13)$ КУО/г) аналогічний показник третьої групи хвоpих $((2,63 \pm 0,12) \mathrm{KУО/г)} \mathrm{(табл.} \mathrm{4.3).} \mathrm{Цей} \mathrm{факт} \mathrm{мо-}$ же вказувати на більшу колонізацію кишковою паличкою просвіту тонкого кишечника хворих, лікованих традиційними методами.

Отже, суттєве зниження колонізації умовнопатогенними ентеробактеріями виділень із дренажів спостерігали на п’яту добу післяопераційного періоду в першій (стадія компенсації) та третій (використання запропонованого комплексу лікувальних заходів) групі пацієнтів. Друга група хворих не зазнала значної позитивної динаміки в плані зниження обсіменіння виділень 3 дренажів у досліджуваний післяопераційний період.

Кількісний рівень Е. coli у виділеннях із НГІ зонда в перший день після операції в другій та третій групі хворих був майже на одному рівні. Зниження обсіменіння кишковою паличкою досліджуваного матеріалу на третій день після операції також було відмічено в обох групах хворих. Проте на п'ятий день в третій групі спостеріга- ли значно меншу колонізацію кишковою паличкою вмісту із НГІ зонда, ніж у другій групі. Це свідчить про швидше відновлення мікробіоценозу тонкого кишечника в третій групі хворих. Кількісний склад облігатних анаеробних мікроорганізмів, виділених із зонда другої групи хворих, зазнав істотніших змін, ніж третьої групи.

Так, на третій день після операції в другій групі хворих було виявлено зниження кількості біфідо- і лактобактерій у виділеннях із НГІ зонда майже на третину (3,80 KУО/г - в перший день після операції, 2,73 КУО/г - в третій день). В третій групі хворих цей показник був стабільним ( 4,0 КУО/г - в перший день після операції, 4,13 КУО/г - в третій день). На п'яту добу після операції показники кількісного рівня облігатних анаеробних мікроорганізмів зросли в обох групах (5,47 КУО/г - в другій групі хворих, 6,09 КУО/Г - в третій групі).

Висновки. 1. У хворих на гостру злукову кишкову непрохідність спостерігається дисбіоз кишкового вмісту, який більш виражений у стадії декомпенсації. 2. При розвитку синдрому кишкової недостатності спостерігається бактеріальна транслокація в черевну порожнину. 3. Застовування запропонованого способу лікування забезпечило більш швидке відновлення якісного та кількісного складу мікрофлори тонкої кишки і дозволило зменшити частоту післяопераційних ускладнень та рівень летальності. 


\section{СПИСОК ЛІТЕРАТУРИ}

1. Липатов В. А. Спаечная болезнь брюшины как поли-этиологическое мультифакториальное заболевание / В. А. Липатов, А. Д. Мясников // Сборник материалов Российской научной конференции с международным участием “Медико-биологические аспекты мультифакториальной патологии”. В 2-х томах - Курск : КГМУ, 2006. - Том 1. - С. 324-329.

2. Осложненные и нерешенные вопросы диагностики и лечения острого аппендицита, острой кишечной непроходимости и сочетанной травмы : По материалам науч.-практ. конф. хирургов РФ, Санкт-Петербург, 3-4 июня 2004 / М. В. Кукош, С. Г. Измайлов, В. Н. Гречко, Г. И. Гомозов // Мир фармации и медицины. - 2008. - № 14. - С. 34-38.

3. Diagnosis of small intestinal bacterial overgrowth in the clinical practice // M. Gabrielli, G. D’angelo, T. Dirienzo [et al.] // European Review for Medical and Pharmacological Sciences. 2013. - Vol. 17 (Suppl 2). - P. 30-35.

4. Гостищев В. К. Бактериальная транслокация при острой кишечной непроходимости / В. К. Гостищев // Медицина и экология. - 2015. - № 1. - С. 57-61.

\section{REFERENCES}

1. Lipatov, V.A. \& Myasnikov, A.D. (2006). Spaechnaya bolezn bryushiny kak polietiologicheskoe multifaktorialnoe zabolevanie [Adherent peritoneal disease as a polyethological multifactorial disease]. Sbornik materialov Rossiyskoy nauchnoy konferentsii $s$ mezhdunarodnym uchastiem "Mediko-biologicheskie aspekty multifaktorialnoy patologii". $V$ 2-h tomakh - Collection of materials of the Russian scientific conference with international participation "Medico-biological aspects of multifactorial pathology". In 2 volumes. Kursk: KGMU [in Russian].

2. Kukosh, M.V., Izmaylov, S.G., Grechko, V.N., \& Gomozov, G.I. (2008). Oslozhnennyie i nereshennye voprosy diagnostiki i lecheniya ostrogo appenditsita, ostroy kishechnoy neprohodimosti i sochetannoy travmy [Complicated and unresolved issues of diagnosis and treatment of acute appendicitis, acute intestinal obstruction and combined trauma]. Po materialam nauch.-prakt. konf. khirurgov RF, Sankt-Peterburg - Based on Materials of Scientific-practical Conference of Russian Surgeons, St. Petersburg. Mir farmatsii meditsyny - World of Medicine Pharmacy, (14), 34-38 [in Russian].

3. Gabrielli, M., D’angelo, G., Dirienzo, T., Scarpellini, E., \& Ojetti, V. (2013). Diagnosis of small intestinal bacterial overgrowth in the clinical practice [Diagnosis of small intestinal bacterial overgrowth in the clinical practice]. European Review for Medical and Pharmacological Sciences, 17 (Suppl. 2), 30-35. 4. Gostishchev, V.K. (2015). Bakterialnaya translokatsiya pri ostroy kishechnoy neprokhodimosti [Bacterial translocation in
5. Салато О. В. Исследование транслокации бактерий при механической непроходимости тонкой кишки // Бюллетень Восточно-Сибирского научного центра Сибирского отделения Российской Академии медицинских наук. - 2008. 4 (62). - C. 76-79.

6. Chang Hwan Choi. The role of small intestinal overgrowth in functional gastrointestinal disorders / Chang Hwan Choi, Sae Kyung Chang // Journal of neurogastroenterology and Motility. 2016. - Vol. 22. P. 3-5.

7. Гриценко Є. М. Ультразвукова діагностика синдрому ентеральної недостатності при гострій хірургічній патології органів черевної порожнини у дітей / Є. М. Гриценко, В. С. Барійчук, М. I. Гриценко // Матеріали 3-го Конгресу Української асоціації спеціалістів ультразвукової діагностики, м. Одеса, 9-11 червня. - 2008 - С. 30-31.

8. Методики клинических лабораторных исследований. Т. 3. Клиническая микробиология : справочное пособие / под ред. В. В. Меньшикова. - М. : Лабора, 2009. - 880 с.

acute intestinal obstruction.]. Meditsina i ekologiya - Medicine and Ecology, (1), 57-61 [in Russian].

5. Salato, O.V. (2008). Issledovanie translokatsii bakteriy pri mekhanicheskoy neprokhodimosti tonkoy kishki [Study of translocation of bacteria in mechanical obstruction of the small intestine]. Byulleten Vostochno-Sibirskogo nauchnogo tsentra Sibirskogo otdeleniya Rossiyskoy Akademii meditsinskih nauk Journal of the East Siberian Scientific Center SBRAMS, 4 (62), 76-79 [in Russian]

6. Chang Hwan Choi, \& Sae Kyung Chang. (2016). The role of small intestinal overgrowth in functional gastrointestinal disorders. Journal of Neurogastroenterology and Motility, 22, 3-5.

7. Hrytsenko, Ye.M., Bariichuk, M.I., \& Hrytsenko, M.I. (2008). Ultrazvukova diahnostyka syndromu enteralnoi nedostatnosti pry hostrii khirurhichnii patolohii orhaniv cherevnoi porozhnyny $\mathrm{u}$ ditei [Ultrasonic diagnostics to the syndrome of entarial deficiency in case of chronic obstructive pulmonary diseases in children]. Materialy 3-ho Konhresu Ukrainskoi asotsiatsii spetsialistiv ultrazvukovoi diahnostyky, m. Odesa - Materials of the 3rd Congress of the Ukrainian Association of Specialists of Ultrasound and Diagnostics. Odesa. (pp.30-31) [in Ukrainian]. 8. Menshikov, M.M. (Eds.) (2009). Metodiki klinicheskikh laboratornykh issledovaniy. Klinicheskaya mikrobiologiya : spravochnoe posobie [Methods of clinical laboratory research. Clinical microbiology: a reference manual]. Moscow: Labora [in Russian]. 
A. YE. BURAK

I. Horbachevsky Ternopil State Medical University

\title{
FEATURES OF BACTERIAL CONTAMINATION OF PERITONAMEUM AND INTESTINE IN DIFFERENT STAGES OF ACUTE ADHESIVE SMALL BOWEL OBSTRUCTION AND ITS CORRECTION
}

\begin{abstract}
The aim of the work: to find out the features of bacterial contamination of the peritoneum and intestine at different stages of acute articular small bowel obstruction and its correction.

Materials and Methods. 152 patients with acute articular small bowel obstruction were examined and underwent surgery. 58 (38.2 \%) patients of them were at the stage of compensation and 94 (61.8\%) patients were at the stage of decompensation. In order to study the level of bacterial translocation, the bacteriologic test of excretion from drainages and nasogastrointestinal bougie (NGI) bougie were performed in the dynamics of treatment in the postoperative period.

Results and Discussion. Quantitative and qualitative composition of microflora of small intestine and peritoneal exudate under the influence of complex treatment with intestinal lavage using $0.9 \%$ sodium chloride solution in combination with oxygen therapy and enteral nutrition solution "Peptaumen" in patients with acute articular small bowel obstruction at the stage of compensation and decompensation was studied. Lower colonization of the intestine and contamination of the abdominal cavity by E. coli, conditional pathogenic microorganisms was detected and also a more rapid recovery of the biocenosis of intestine in the application of the developed complex of measures allowed reducing the level of postoperative complications and mortality.
\end{abstract}

Key words: acute gastrointestinal obstruction; bacterial translocation; nasogastro intestinal bougie.

\author{
A. Е. БУРАК
}

ГВУЗ “Тернопольский государственный медицинский университет имени И. Я. Горбачевского МЗ Украины”

\section{ОСОБЕННОСТИ БАКТЕРИАЛЬНОЙ КОНТАМИНАЦИИ ПЕРИТОНЕУМА И КИНІКИ ПРИ РАЗНЫХ СТАДИЯХ ОСТРОЙ СПАЕЧНОЙ ТОНКОКИШЕЧНОЙ НЕПРОХОДИМОСТИ И ЕЕ КОРРЕКЦИИ}

\footnotetext{
Цель работы: выяснить особенности бактериальной контаминации перитонеума и кишки при различных стадиях острой спаечной тонкокишечной непроходимости и ее коррекции.

Материалы и методы. Обследовано и прооперировано 152 больных с острой спаечной тонкокишечной непроходимостю. Из них 58 (38,2 \%) пациентов были в стадии компенсации и 94 (61,8 \%) пациентов - в стадии декомпенсации. С целью изучения уровня бактериальной транслокации выполняли бакпосев выделений из дренажей и назогастроинтестинального (НГИ) зонда в динамике лечения в послеоперационном периоде.

Результаты исследований и их обсуждение. В работе изучено количественный и качественный состав микрофлоры тонкой кишки и перитонеального экссудата под влиянием комплексного лечения с применением лаважа кишечника 0,9 \% раствором натрия хлорида в сочетании с оксигенотерапией и энтеральным питанием раствором “Пептамен” у больных с острой спаечной тонкокишечной непроходимостю в стадии компенсации и декомпенсации. Выявлено меньшую колонизацию кишечника и контаминацию брюшной полости кишечной палочкой, условно-патогенными микроорганизмами, и более быстрое восстановление биоценоза тонкой кишки при применении разработанного комплекса мер позволило снизить уровень послеоперационных осложнений и летальности.
}

Ключевые слова: острая спаечная кишечная непроходимость; бактериальная транслокация; назогастроинтестинальный зонд. 